\title{
Putting value back into the "V" of wRVU
}

William D. Gaillard, MD, and Howard P. Goodkin, MD, PhD

Neurology ${ }^{\circledR}$ 2020;94:57-58. doi:10.1212/WNL.0000000000008796

"I feel like just another spoke in a great big wheel" lamented the American singer/songwriter Bob Seeger in the song "I Feel like a Number." Increasingly, physicians in many specialties are sharing a similar lament of depersonalization. Troubled that they have been reduced to a widget, many express that we have become "just another statistic on a sheet"; a commodity assessed by our ability to meet work relative value unit (wRVU) targets at the 60th percentile or higher.

Depersonalization is often cited as among the most pernicious hallmarks of physician burnout. ${ }^{1,2}$ Combatting burnout requires creating an environment in which we are allowed to follow our drive by spending a portion of our day doing work that is personally meaningful. Yet progressively we find ourselves in environments in which there is a disproportional emphasis on meeting wRVU targets. These targets often cannot be attained without using time previously reserved for personally meaningful work such as mentoring, teaching, or engaging in research; the inherent unspoken message is that of volume over value, with the untoward effect that time spent with patients and the quality of the care is reduced.

In this issue of Neurology ${ }^{\circledR}$, Zupanc et al., ${ }^{3}$ of the Child Neurology Society relative value unit (RVU) task force, share the results of a survey that was sent to 25 small ( $<5$ faculty members) and large ( $>20$ faculty members) child neurology academic departments and private practices/ organizations. The survey inquired on a number of subjects (RVU requirements, salary and compensation, time allotted for new and established patients, administrative and teaching mandates, clinical and administrative support, expected face-to-face time with patients, protected time, and educational opportunities) with the goal of gaining practical insight into the functioning of each of those departments and organizations.

While the survey found many similarities across the domains investigated, there were exceptions. A critical difference was that those in private organizations and practices reported higher overall satisfaction rates than did those in academic departments. While those in a private setting reported feeling independent and in control of their destiny, symptoms of burnout were reported among the faculty in all but one of the surveyed academic programs. Although the survey does not appear to have specifically sought to identify the exact causes of burnout in these academic departments, the respondents outlined multiple challenges that could be contributing, including an overreliance on wRVU targets as the sole determinants of base salaries and total compensation.

wRVUs were introduced with a noble goal. However, as with any system, it is based on assumptions and has its limitations. As a surrogate marker for comparing productivity across institutions, it assumes homogeneity within a given profession and across the settings being compared. As each of us is as different as the patients we treat, and, as demonstrated by the survey results, we work in environments with marked variances in physician support for patient care and care settings, child neurology violates this initial assumption. Other limitations highlighted in the task force report include (1) the effect that residents and advance practice providers can have in exaggerating the reported wRVU for an individual provider; (2) an important back-of-the-envelope calculation that effectively demonstrates the fallacy of relying on reimbursement from wRVUs alone to set the salary of a child neurologist; (3) the lack of transparency regarding the methods by which the data are collected and calculated by external benchmarking firms to derive wRVU targets; and (4) the

\author{
Correspondence \\ Dr. Goodkin \\ Hpg9v@virginia.edu
}

RELATED ARTICLE

Child neurology in the 21st century: More than the sum of our RVUs

Page 75 
failure of a wRVU-only compensation model to account for the time spent in education and research, missions that add value and are the reasons that many choose to pursue academic neurology. The task force further emphasizes how such a system may proportionally negatively influence a junior faculty's quest for promotion. In short, wRVUs are numbers that are not capable of assessing the quality or the complexity of the care we provide, nor our many contributions that are not wRVUgenerating. Therefore, the task force is correct in recommending that it not be the sole determinant of productivity or compensation within the academic setting.

We posit that we all share common values of not merely seeing patients but caring for our patients, of advancing care of children (and adults, for these arguments may well be generalizable) with neurologic disorders through basic, translational, and clinical research as well as quality improvement initiatives, and of educating the next generation of physicians at all stages of their training. The task force provides a number of recommendations of how to move forward as we begin to create a new business model in which these values are incorporated into our measures of effort and productivity (and, thus, compensation). These changes will not happen if we do not begin to understand better the systems in which we function and team locally with our administrative leadership and nationally with our professional organizations to effect change. To do so, we will likely need to spend time educating others and look for new opportunities. For example, while the electronic medical record (EMR) is currently viewed as a major hindrance to work flow and work satisfaction, it remains in its early stages of development. Thus there is no reason why the EMR cannot be harnessed to ease our work, enhance our care, and improve outcomes. ${ }^{4}$

This survey and the recommendations of the task force represent only the initial stages of putting value - the value we provide to our patients and the value we provide to our medical schools and health systems-back into the $\mathrm{V}$ of wRVU.

\section{Study funding}

No targeted funding reported.

\section{Disclosure}

W.D.G. has received support from the NIH and the Band Foundation and serves as an associate editor of Epilepsy Research. H.P.G. has received support from the NIH, the Band Foundation, and institutional support from the University of Virginia for research; serves as an associate editor of Epilepsy Research; and receives royalties from UpToDate and Wolters Kluwer. Go to Neurology.org/N for full disclosures.

\section{References}

1. Miyazaki JM, Rheuame C, Gulya L, et al. Qualitative study of burnout, career satisfaction, and well-being among US neurologists in 2016. Neurology 2017;89: $1730-1738$.

2. Busis NA, Shanafelt TD, Keran CM, et al. Burnout, career satisfaction, and well being among US neurologists in 2016. Neurology 2017;88:797-808.

3. Zupanc ML, Cohen BH, Kang PB, et al. Child neurology in the 21st century: more than the sum of our RVUs. Neurology 2020;94:75-82.

4. Mbwana JS, Grinspan ZM, Bailey R, et al. Using EHRs to advance epilepsy care. Neurol Clin Pract 2019;9:83-88. 


\title{
Neurology
}

\author{
Putting value back into the " $V$ " of wRVU \\ William D. Gaillard and Howard P. Goodkin
}

Neurology 2020;94;57-58 Published Online before print December 24, 2019

DOI 10.1212/WNL.0000000000008796

This information is current as of December 24, 2019

\section{Updated Information \& Services}

\section{References}

Subspecialty Collections

\section{Permissions \& Licensing}

\section{Reprints}

including high resolution figures, can be found at: http://n.neurology.org/content/94/2/57.full

This article cites 4 articles, 4 of which you can access for free at: http://n.neurology.org/content/94/2/57.full\#ref-list-1

This article, along with others on similar topics, appears in the following collection(s):

All Clinical Neurology

http://n.neurology.org/cgi/collection/all_clinical_neurology

All Practice Management

http://n.neurology.org/cgi/collection/all_practice_management

Billing

http://n.neurology.org/cgi/collection/billing

Health care reform

http://n.neurology.org/cgi/collection/health_care_reform

Models of care

http://n.neurology.org/cgi/collection/models_of_care

Information about reproducing this article in parts (figures,tables) or in its entirety can be found online at:

http://www.neurology.org/about/about_the_journal\#permissions

Information about ordering reprints can be found online:

http://n.neurology.org/subscribers/advertise

Neurology ${ }^{\circledR}$ is the official journal of the American Academy of Neurology. Published continuously since 1951, it is now a weekly with 48 issues per year. Copyright @ 2019 American Academy of Neurology. All rights reserved. Print ISSN: 0028-3878. Online ISSN: 1526-632X.

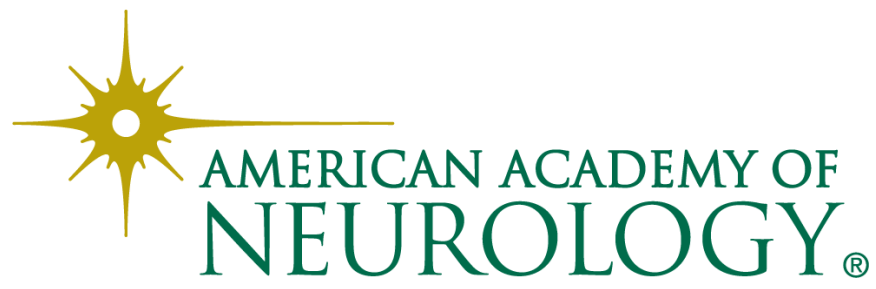

